\title{
Retinoic acid modulation of thyroid dual oxidase activity in rats and its impact on thyroid iodine organification
}

\author{
Mônica Mühlbauer ${ }^{1}$, Alba Cenélia Matos da Silva ${ }^{1}$, Michelle Porto Marassi ${ }^{1}$, Alexandre Lopes Lourenço ${ }^{2}$, \\ Andrea Claudia Freitas Ferreira ${ }^{1}$ and Denise Pires de Carvalho ${ }^{1}$ \\ ${ }^{1}$ Laboratório de Fisiologia Endócrina, Instituto de Biofísica Carlos Chagas Filho, CCS - Bloco G - Cidade Universitária, Ilha do Fundão, Rio de Janeiro $21949-900$, \\ Brazil \\ ${ }^{2}$ Laboratório de Produtos Naturais, Instituto de Farmacologia Básica e Clínica, Universidade Federal do Rio de Janeiro, Rio de Janeiro, RJ-CEP 21941 -901 Brazil \\ (Correspondence should be addressed to A C F Ferreira; Email: deiaclau@biof.ufrj.br)
}

\begin{abstract}
The sodium-iodide symporter (NIS) mediates iodide uptake into the thyrocytes, which is important for the diagnosis and therapy of thyroid disorders. Decreased ability to uptake iodide in thyroid carcinomas reduces the efficacy of radioiodine therapy, and retinoic acid (RA) treatment reinduces iodide uptake. The effectiveness of treatment depends not only on iodide uptake but also on the ability of thyrocytes to organify iodine, which is catalyzed by thyroperoxidase (TPO) in the presence of $\mathrm{H}_{2} \mathrm{O}_{2}$. Our goal was to determine the influence of RA on thyroid iodide uptake, iodine organification, and TPO and dual oxidase $(\mathrm{DuOx})$ activities. Normal rats were treated with all-trans-RA or 13-cis-RA (100 or $1500 \mu \mathrm{g} / 100 \mathrm{~g}$ body weight (b.w.), s.c.) for 14 and 28 days. The $2 \mathrm{~h}$ thyroid radioiodine content significantly decreased in rats treated
\end{abstract}

with all-trans-RA $(100 \mu \mathrm{g} / 100 \mathrm{~g}$ b.w.) for 14 days. In this group, NIS function and TPO activity were unchanged, whereas DuOx activity was significantly decreased, which might have contributed to the decrease in iodine organification. Both doses of 13-cis-RA for 28 days increased the $15 \mathrm{~min}$ thyroid radioiodine uptake, while the $2 \mathrm{~h}$ radioiodide uptake increased only in rats treated with the highest dose of 13-cis-RA. While TPO activity did not change, $\mathrm{H}_{2} \mathrm{O}_{2}$ generation was increased in this group, and serum thyroxine levels were normal. Since radioiodine half-life in the thyroid gland is important for treatment efficacy, our results highlight the importance of correctly choosing the RA isomer, the time and the dose of treatment, in order to improve the efficacy of radioiodine therapy.

Journal of Endocrinology (2010) 205, 271-277

\section{Introduction}

The content of iodine in the thyroid gland depends on the presence of proteins that are necessary for iodide uptake through the basolateral membrane of thyrocytes and its incorporation into the acceptor protein thyroglobulin (TG) at the apical surface of these cells (DeGroot \& Niepomniszcze 1977, Kopp 2005). The sodium-iodide symporter (NIS) is responsible for iodide uptake through the thyroid cell basolateral membrane against its electrochemical gradient. At the apical pole of thyrocytes, intracellular iodide is transported through pendrin (PDS; Royaux et al. 2000) into the follicular lumen and then incorporated into $\mathrm{Tg}$. Iodide oxidation and organification occur at the apical surface of the follicular cell, and these reactions are catalyzed by thyroperoxidase (TPO) in the presence of $\mathrm{H}_{2} \mathrm{O}_{2}$. Thus, thyroid iodide organification depends on TPO activity, which is modulated by the concentration of iodide and $\mathrm{H}_{2} \mathrm{O}_{2}$ (DeGroot \& Niepomniszcze 1977, Kopp 2005). In the presence of sufficient amounts of iodine, the limiting step for thyroid hormone biosynthesis is the availability of $\mathrm{H}_{2} \mathrm{O}_{2}$, which is generated by thyroid dual oxidase ( $\mathrm{DuOx}$; Corvilain et al. 1991, Dupuy et al. 1999).

Treatment with retinoic acid (RA) was shown to increase NIS, TPO, and TG mRNA levels in cancer cell lines and to decrease Nis mRNA levels and iodide uptake in normal rat thyroid cell line (Schmutzler et al. 1997). In normal thyroid cell line, RA reduces TSH receptor mRNA levels and increases TPO and TG mRNA levels (Schmutzler et al. 1997, Kurebayashi et al. 2000). On the other hand, some authors demonstrated that RA suppresses the accumulation of TPO and TG mRNA stimulated by TSH in a time- and dose-dependent manner in cultures of human thyrocytes (Arai et al. 1991, Namba et al. 1993, Del Senno et al. 1993, 1994). However, the possible effect of RA on thyroid $\mathrm{DuOx}$ has not been assessed so far.

RA is widely used in dermatological treatment and thyroid cancer management (Verschoore et al. 1993, Coelho et al. 2004), although the effects of this drug on normal thyroid function are poorly defined. We have recently demonstrated that 13-cis-RA is able to increase thyroid radioiodide uptake in normal female rats (Silva et al. 2009); however, the effect on the thyroid of male rats was not evaluated. 
Therefore, the aim of the present study was to analyze the influence of RA treatment on thyroid iodide uptake, serum thyroxine $\left(\mathrm{T}_{4}\right)$, and TPO and DuOx activities in male rats.

\section{Materials and Methods}

\section{Materials}

All-trans-RA and 13-cis-RA were purchased from Sigma Chemical Co. Tris(hydroxymethyl)aminomethane, glucose, and potassium iodide were purchased from Merck. Fetal bovine serum was purchased from Cultilab (Rio de Janeiro, RJ, Brazil). Glucose oxidase (grade I) was purchased from Boehringer, and $\mathrm{Na}^{-125}{ }^{12}$ was purchased from Amersham.

\section{Animals}

Adult male Wistar rats weighing $250-300 \mathrm{~g}$ were housed under controlled conditions of temperature $\left(24 \pm 1^{\circ} \mathrm{C}\right)$ and light (12 h light starting at $0700 \mathrm{~h}$ ) with water and food made available ad libitum. The study conforms to the Guide for the Care and Use of Laboratory Animals published by the US National Institutes of Health (NIH Publication No. 85-23, revised 1996), and was approved by the Institutional Animal Welfare Committee (CAUAP/UFRJ).

Rats were randomly divided into the following groups: control, all-trans-RA and 13-cis-RA. RA was administered in the dose of $100 \mu \mathrm{g} / \mathrm{kg}$ body weight (b.w.) s.c. daily for 14 days according to Coya et al. (1997), and in the doses of 100 and $1500 \mu \mathrm{g} / \mathrm{kg}$ b.w. for 28 days. The dose of $1500 \mu \mathrm{g} / \mathrm{kg}$ b.w. is similar to that used in the treatment of thyroid cancer in humans (Coelho et al. 2004). Both all-trans-RA and 13-cis-RA were dissolved in DMSO and suspended in propylene glycol $(1: 1, \mathrm{v} / \mathrm{v})$. Rats from all experimental groups were killed $24 \mathrm{~h}$ after the last injection.

\section{TPO preparation}

TPO extraction from rat thyroids was performed as previously described (Moura et al. 1989, Ferreira et al. 2005). Pools of two rat thyroids were minced and homogenized in $0.5 \mathrm{ml}$ of $50 \mathrm{mM}$ Tris- $\mathrm{HCl}$ buffer, $\mathrm{pH} 7 \cdot 2$, containing $1 \mathrm{mM} \mathrm{KI}$, using an Ultra-Turrax homogenizer (Staufen, Germany). The homogenate was centrifuged at $100000 \mathrm{~g}$ at $4{ }^{\circ} \mathrm{C}$ for $1 \mathrm{~h}$. The pellet was suspended in $0.5 \mathrm{ml}$ digitonin $(1 \%, \mathrm{w} / \mathrm{v})$ and incubated at $4{ }^{\circ} \mathrm{C}$ for $24 \mathrm{~h}$ to solubilize the peroxidase. The digitonin-treated suspension was centrifuged at $100000 \boldsymbol{g}$ at $4{ }^{\circ} \mathrm{C}$ for $1 \mathrm{~h}$, and the supernatant containing the solubilized TPO was used for the assays. Protein content was determined by the method of Bradford (1976).

\section{Thyroid peroxidase activity}

The TPO iodide oxidation activity was measured as previously described (Nakashima \& Taurog 1978, Pommier 1978, Moura et al. 1989, Carvalho et al. 1994, Ferreira et al. 2005). The assay mixture contained $1.0 \mathrm{ml}$ of freshly prepared $50 \mathrm{mM}$ sodium phosphate buffer, $\mathrm{pH} 7 \cdot 4$, containing $24 \mathrm{mM} \mathrm{KI}$ and $11 \mathrm{mM}$ glucose, and increasing amounts $(20-80 \mu \mathrm{l})$ of solubilized TPO. The final volume was adjusted to $2 \cdot 0 \mathrm{ml}$ with $50 \mathrm{mM}$ sodium phosphate buffer, $\mathrm{pH} 7 \cdot 4$, and the reaction was started by the addition of $10 \mu \mathrm{l}$ of $0 \cdot 1 \%$ glucose oxidase (Boehringer Grade I). The increase in absorbance at $353 \mathrm{~nm}$ (tri-iodide production) was registered for $4 \mathrm{~min}$ on a Hitachi spectrophotometer (U-3300). The $\Delta \mathrm{A}_{353 \mathrm{~nm}} / \mathrm{min}$ was determined from the linear portion of the reaction curve, and one unit $(\mathrm{U})$ of TPO corresponds to $\Delta \mathrm{A}_{353 \mathrm{~nm}} / \mathrm{min}=1 \cdot 0$. The enzymatic activity is expressed as $\mathrm{U} / \mathrm{g}$ protein.

\section{$\mathrm{DuOx}$ preparation}

For DuOx preparation, the excised thyroid glands remained at $4{ }^{\circ} \mathrm{C}$ for $24 \mathrm{~h}$ in $50 \mathrm{mM}$ sodium phosphate buffer, $\mathrm{pH} 7 \cdot 2$, containing $0.25 \mathrm{M}$ sucrose, $0.5 \mathrm{mM}$ dithiothreitol, $1 \mathrm{mM}$ EGTA, $5 \mu \mathrm{g} / \mathrm{ml}$ aprotinin, and $34.8 \mu \mathrm{g} / \mathrm{ml}$ phenylmethylsulphonyl fluoride (PMSF) before homogenization. Then, the homogenate was centrifuged at $100000 \mathrm{~g}$ for $35 \mathrm{~min}$ at $4{ }^{\circ} \mathrm{C}$ and resuspended in $0.5 \mathrm{ml}$ of $50 \mathrm{mM}$ sodium phosphate buffer, $\mathrm{pH} 7 \cdot 2$, containing $0 \cdot 25 \mathrm{M}$ sucrose, $2 \mathrm{mM} \mathrm{MgCl}_{2}$, $5 \mu \mathrm{g} / \mathrm{ml}$ aprotinin, and $34.8 \mu \mathrm{g} / \mathrm{ml}$ PMSF, and stored at $-20{ }^{\circ} \mathrm{C}$ until $\mathrm{H}_{2} \mathrm{O}_{2}$ generation measurements.

$\mathrm{Ca}^{2+}$ - and $\mathrm{NADPH}$-dependent $\mathrm{H}_{2} \mathrm{O}_{2}$-generating activity: $\mathrm{Du} O x$ activity

$\mathrm{H}_{2} \mathrm{O}_{2}$ production was measured as previously described (Leseney et al. 1999, Cardoso et al. 2001). We incubated samples of thyroid particulate fractions at $30^{\circ} \mathrm{C}$ in $1 \mathrm{ml}$ of $170 \mathrm{mM}$ sodium phosphate buffer, $\mathrm{pH} 7 \cdot 4$, containing $1 \mathrm{mM}$ sodium azide, $1 \mathrm{mM}$ EGTA, $1 \mu \mathrm{M}$ FAD, and $1.5 \mathrm{mM} \mathrm{CaCl}_{2}$. The addition of $0.2 \mathrm{mM}$ NADPH started the reaction; aliquots of $100 \mu \mathrm{l}$ were collected at intervals up to $20 \mathrm{~min}$, and mixed with $10 \mu \mathrm{l}$ of $3 \mathrm{M} \mathrm{HCl}$ to stop the reaction and destroy the remaining NADPH. Initial rates of $\mathrm{H}_{2} \mathrm{O}_{2}$ formation were determined from eight aliquots of each assay by following the decrease in $0.4 \mu \mathrm{M}$ scopoletin fluorescence in the presence of HRP $(0.5 \mu \mathrm{g} / \mathrm{ml})$ in $200 \mathrm{mM}$ phosphate buffer, $\mathrm{pH} 7 \cdot 8$, in a Hitachi spectrofluorimeter (F 4000). The excitation and emission wavelengths were 360 and $460 \mathrm{~nm}$ respectively. Specific activities were expressed per milligram protein (nmoles $\mathrm{H}_{2} \mathrm{O}_{2} / \mathrm{h}$ per mg protein).

\section{Thyroid radioiodide content}

We have previously shown that the measurement of radioiodide uptake $15 \mathrm{~min}$ after ${ }^{125} \mathrm{I}-\mathrm{NaI}$ administration (shortterm iodide uptake) reflects iodide transport through the NIS, without influence of in vivo thyroid iodine organification activity (Ferreira et al. 2005, Lima et al. 2006). Thus, in order to evaluate the in vivo NIS function, the animals received $\mathrm{Na}_{-}{ }^{125} \mathrm{I}$ (3700 Bq, i.p., Amersham) $15 \mathrm{~min}$ before decapitation. We also administered $\mathrm{Na}^{125}{ }^{12}$ (3700 Bq, i.p., Amersham) 
$2 \mathrm{~h}$ before decapitation, in order to evaluate both iodide transport and in vivo organification activities (thyroid iodine accumulation). In the thyroid, iodine organification is catalyzed by TPO and consists of binding of iodine to tyrosyl residues of $\mathrm{TG}$, an essential step of thyroid hormone biosynthesis. The radioactivity of the thyroid glands was measured using a gamma counter (LKB) and expressed as percentage of total ${ }^{125}$ I injected per mg of thyroid.

\section{$T_{4}$ measurement}

Serum total $\mathrm{T}_{4}$ concentrations were measured using commercial kits (RIA, Diagnostic Systems Laboratories Inc., TX, USA, or eletrochemiluminescence, Roche Diagnostics). $T_{4}$ RIA sensitivity was of $0.4 \mu \mathrm{g} / \mathrm{dl}$, and inter- and intra-assay coefficients of variation varied from $5 \cdot 6$ to $8 \cdot 6 \%$ and 4 to $5 \cdot 1 \%$ respectively. $\mathrm{T}_{4}$ eletrochemiluminescence assay sensitivity was of $0.42 \mu \mathrm{g} / \mathrm{dl}$, and intra-assay coefficients of variation were of $4 \cdot 2 \%$.

\section{Statistical analysis}

The experiments were repeated at least two times using at least three animals per group in each experiment, so a total number of at least six animals per group were achieved. Results are expressed as mean \pm s.e.m. and were analyzed by unpaired $t$-test. Differences were considered significant when $P<0 \cdot 05$.

\section{Results}

\section{Fourteen days of $R A$ treatment}

Short-term (15 min) thyroid radioiodide uptake was unchanged by the treatment with both isomers of RA in the low dose administered $(100 \mu \mathrm{g} / 100 \mathrm{~g} \mathrm{~b}$.w.) for 2 weeks (Fig. 1A), suggesting that RA did not affect NIS function in the period of time and dose used. On the other hand, treatment with all-trans-RA for 2 weeks produced a significant decrease in thyroid iodine accumulation $(2 \mathrm{~h}$; Fig. 1B). TPO activity was not affected by the treatment with either isomers of RA for 2 weeks when compared to the control group, as shown in Fig. 1C. However, administration of the low dose of all-trans-RA $(100 \mu \mathrm{g} / 100 \mathrm{~g} \mathrm{~b}$.w.) for 2 weeks led to a significant decrease in $\mathrm{H}_{2} \mathrm{O}_{2}$ formation, while treatment with 13-cis-RA had no effect (Fig. 1D), suggesting an inhibitory effect of all-trans-RA on DuOx activity. Despite decreased DuOx activity after 14 days of RA treatment, total serum $\mathrm{T}_{4}$ concentration remained unchanged (Table 1).

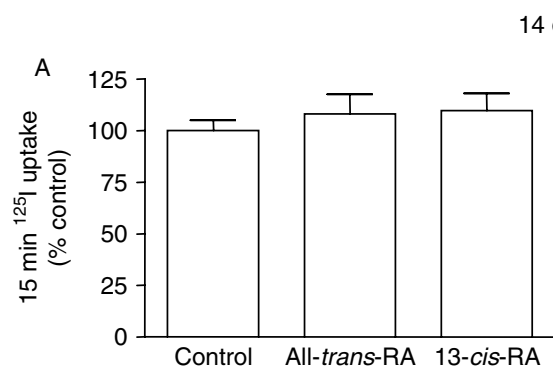

14 days
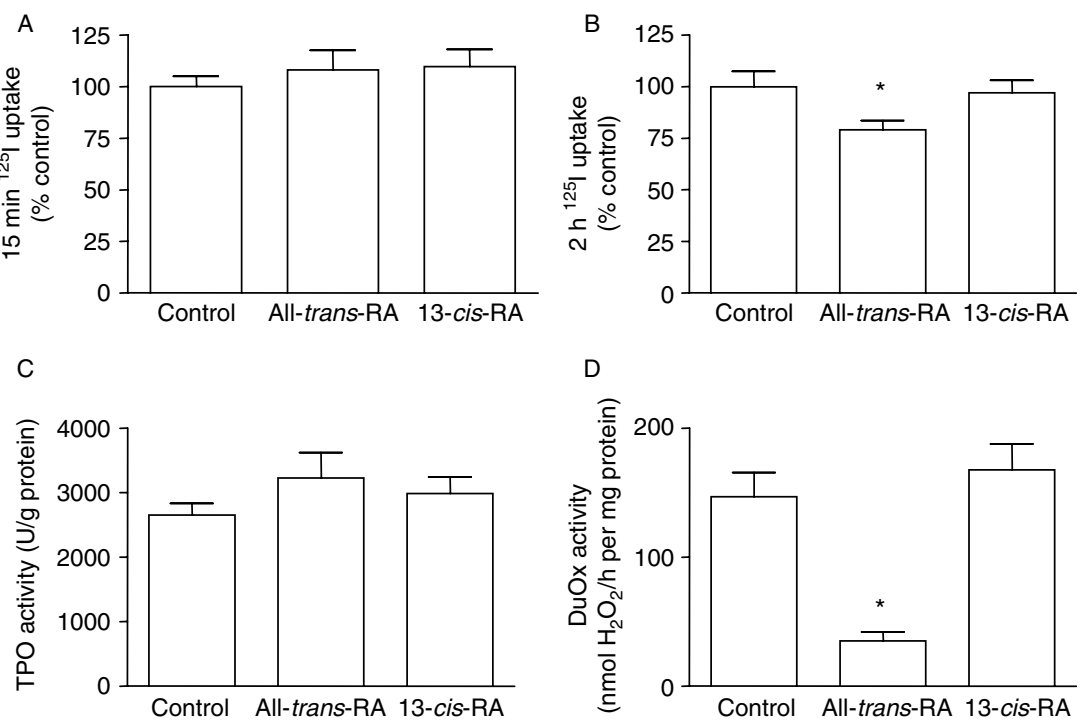

Figure 1 Effect of all-trans-retinoic acid and 13-cis-retinoic acid administered s.c. for 14 days in the dose of $100 \mu \mathrm{g} / \mathrm{kg}$ b.w., daily injections, on some parameters of thyroid function. (A) Short-term iodide uptake $15 \mathrm{~min}$ after radioiodide administration (control $(n=16)$, all-trans-RA $(n=19)$, and 13-cis-RA $(n=19))$. (B) Thyroid iodine accumulation $2 \mathrm{~h}$ after radioiodide administration (control $(n=11)$, all-trans-RA $(n=13)$, and 13-cis-RA $(n=13)$ ). ${ }^{*} P<0.05$ versus control and versus 13 -cis-RA of $100 \mu \mathrm{g} / \mathrm{kg}$ b.w. (C) Thyroperoxidase iodide oxidation activity (control $(n=27)$, all-trans-RA $(n=32)$, and 13-cis-RA $(n=31))$. (D) DuOx $\mathrm{Ca}^{++}$-dependent $\mathrm{H}_{2} \mathrm{O}_{2}$-generating activity (control $(n=12)$, all-trans-RA $(n=10)$, and 13-cis-RA $(n=12))$. ${ }^{*} P<0 \cdot 0001$ versus control and 13-cis-RA. Measurements were performed as described in Materials and Methods. Data are expressed as mean \pm S.E.M. 
Table 1 Effect of all-trans-retinoic acid (RA) and 13-cis-RA for 14 days in the dose of $100 \mu \mathrm{g} / \mathrm{kg}$ body weight (b.w.) on serum total thyroxine $\left(T_{4}\right)$ levels. Results are expressed as mean \pm s.E.M.

$$
\mathbf{T}_{\mathbf{4}}(\mu \mathrm{g} / \mathrm{dl})
$$

\section{Treatment}

Control

$100 \mu \mathrm{g} / \mathrm{kg}$ b.w.

All-trans-retinoic acid

13-cis-retinoic acid

\section{Twenty-eight days of $R A$ treatment}

All-trans-RA treatment did not affect 15-min thyroid radioiodide uptake (Fig. 2A). However, treatment with 13-cis-RA for 28 days significantly increased NIS function in both doses (Fig. 2B), as previously described for thyroid cancers (Coelho et al. 2004) and female rats (Silva et al. 2009).

Treatment with 13-cis-RA at the higher dose $(1500 \mu \mathrm{g} /$ $100 \mathrm{~g}$ b.w.) for 4 weeks produced a significant increase in

the $2 \mathrm{~h}$ thyroid radioiodine content (Fig. 2D), which was unchanged by treatment with all-trans-RA (Fig. 2C).

While TPO activity was not affected by RA treatment in both doses (Fig. 3A and B), DuOx activity was significantly increased in the thyroid of rats treated with 13-cis-RA in the dose of $1500 \mu \mathrm{g} / 100 \mathrm{~g}$ b.w. for 4 weeks (Fig. 3D), but not with all-trans-RA (Fig. 3C). Total serum $\mathrm{T}_{4}$ did not differ among groups (Table 2).

\section{Discussion}

We have shown herein that RA may affect thyroid function not only by interfering with NIS function, but also by modulating DuOx activity. It is well documented that RA stimulates thyroid iodide uptake in human thyroid follicular carcinoma cells (Schmutzler 2001), thyroid cancer (Coelho et al. 2004), and thyroid gland of female rats (Silva et al. 2009). We now demonstrate that although 28 days of treatment with 13-cis-RA stimulates radioiodide uptake, in fact, 14 days

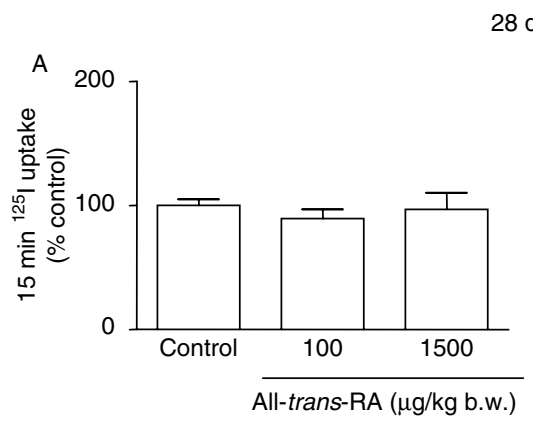

28 days
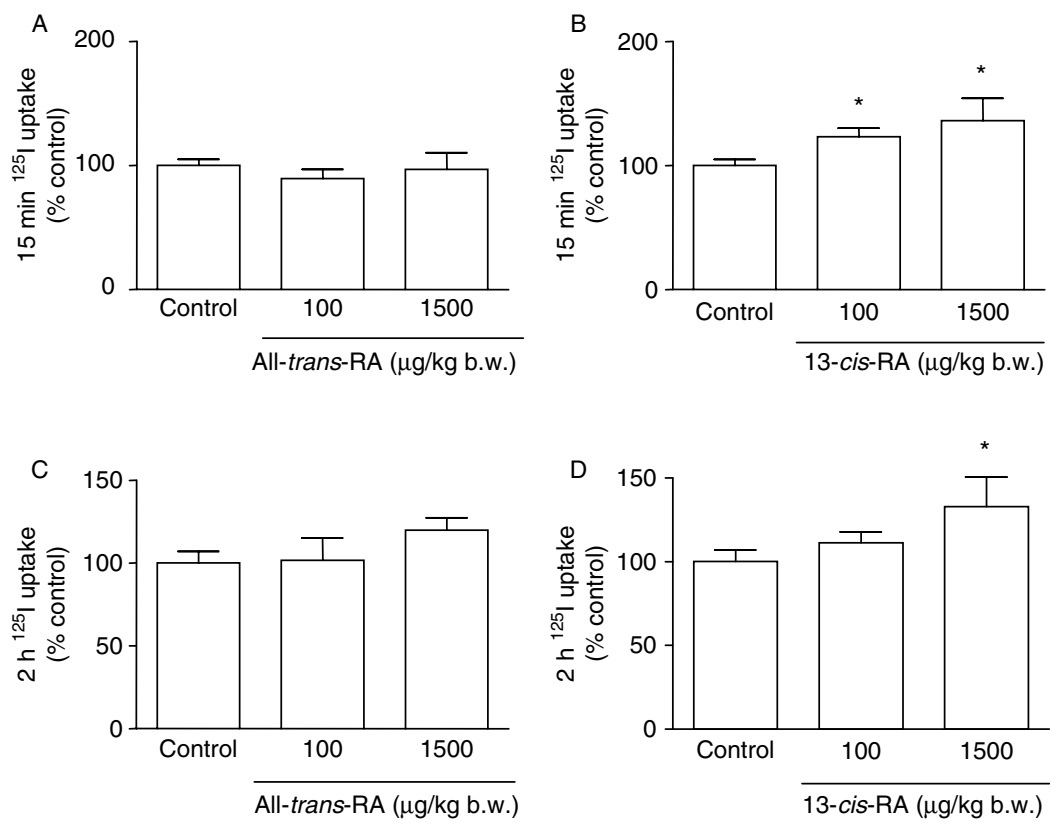

Figure 2 Effect of all-trans-retinoic acid and 13-cis-retinoic acid administered s.c. for 28 days in the doses of 100 and $1500 \mu \mathrm{g} / \mathrm{kg}$ b.w., daily injections, on thyroid iodide uptake (15 min) and accumulation (2 h). (A) Short-term iodide uptake $15 \mathrm{~min}$ after radioiodide administration in rats treated with all-trans-retinoic acid (control $(n=17)$, all-trans-RA of $100 \mu \mathrm{g} / \mathrm{kg}$ b.w. $(n=11)$, and all-trans-RA of $1500 \mu \mathrm{g} / \mathrm{kg}$ b.w. $(n=7))$. (B) Short-term iodide uptake $15 \mathrm{~min}$ after radioiodide administration in rats treated with 13-cis-retinoic acid (control $(n=17), 13$-cis-RA of $100 \mu \mathrm{g} / \mathrm{kg} \mathrm{b.w.}(n=11)$, and 13-cis-RA of $1500 \mu \mathrm{g} / \mathrm{kg}$ b.w. $(n=7))$. ${ }^{*} P<0 \cdot 05$ versus control. (C) Thyroid iodine accumulation $2 \mathrm{~h}$ after radioiodide administration in rats treated with all-trans-retinoic acid (control $(n=24)$, all-trans-RA of $100 \mu \mathrm{g} / \mathrm{kg}$ b.w. $(n=12)$, and all-trans-RA of $1500 \mu \mathrm{g} / \mathrm{kg}$ b.w. $(n=14)$ ). (D) Thyroid iodine accumulation $2 \mathrm{~h}$ after radioiodide administration in rats treated with 13-cis-retinoic acid (control $(n=24), 13$-cis-RA of $100 \mu \mathrm{g} / \mathrm{kg} \mathrm{b.w.}(n=12)$, and 13 -cis-RA of $1500 \mu \mathrm{g} / \mathrm{kg}$ b.w. $(n=14)) .{ }^{*} P<0.05$ versus control. Measurements were performed as described in Materials and Methods. Data are expressed as mean \pm S.E.M. 

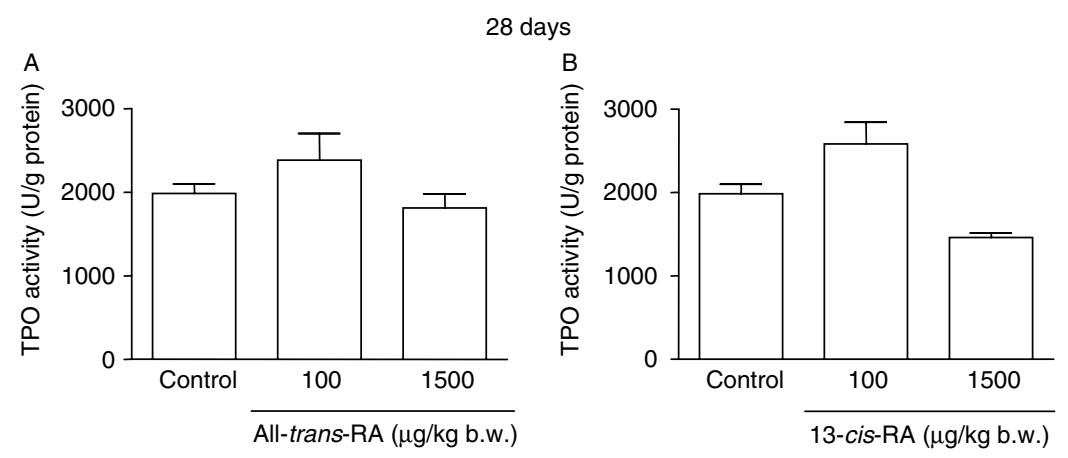

C

D
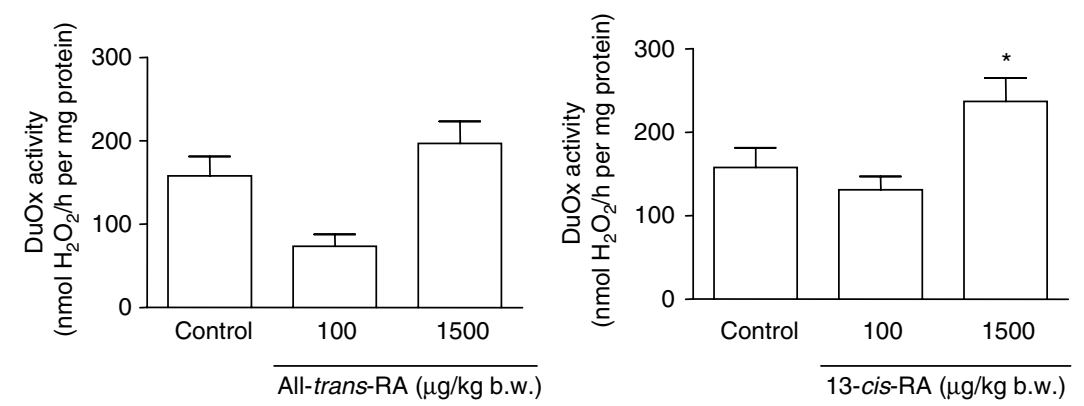

Figure 3 Effect of all-trans-retinoic acid and 13-cis-retinoic acid administered s.c. for 28 days in the doses of 100 and $1500 \mu \mathrm{g} / \mathrm{kg}$ b.w., daily injections, on thyroperoxidase and DuOx activities. (A) Thyroperoxidase iodide oxidation activity in the thyroid of rats treated with all-trans-retinoic acid (control $(n=26)$, all-trans-RA of $100 \mu \mathrm{g} / \mathrm{kg}$ b.w. $(n=23)$, and all-trans-RA of $1500 \mu \mathrm{g} / \mathrm{kg}$ b.w. $(n=7))$. (B) Thyroperoxidase iodide oxidation activity in the thyroid of rats treated with 13-cis-retinoic acid (control $(n=26), 13$-cis-RA of $100 \mu \mathrm{g} / \mathrm{kg}$ b.w. $(n=22)$, and 13-cis-RA of $1500 \mu \mathrm{g} / \mathrm{kg}$ b.w. $(n=7))$. (C) DuOx Ca ${ }^{++}$-dependent $\mathrm{H}_{2} \mathrm{O}_{2}$-generating activity in the thyroid of rats treated with all-trans-retinoic acid (control $(n=17)$, all-trans-RA of $100 \mu \mathrm{g} / \mathrm{kg}$ b.w. $(n=9)$, and all-trans-RA of $1500 \mu \mathrm{g} / \mathrm{kg}$ b.w. $(n=10))$. (D) DuOx Ca ${ }^{++}$-dependent $\mathrm{H}_{2} \mathrm{O}_{2}$-generating activity in the thyroid of rats treated with 13-cis-retinoic acid (control $(n=17)$, 13-cis-RA of $100 \mu \mathrm{g} / \mathrm{kg}$ b.w. $(n=7)$, and 13-cis-RA of $1500 \mu \mathrm{g} / \mathrm{kg}$ b.w. $(n=10))$. ${ }^{*} P<0 \cdot 05$ versus control and versus 13 -cis-RA of $100 \mu \mathrm{g} / \mathrm{kg}$ b.w. Measurements were performed as described in Materials and Methods.

Data are expressed as mean \pm s.E.M.

of treatment with all-trans-RA decreased thyroid iodide content, which has been shown to be related to decreased thyroid iodide organification. DuOx activity was reduced in this group, while NIS function and TPO activity were not affected. It is known that the availability of $\mathrm{H}_{2} \mathrm{O}_{2}$ is a limiting step for iodine organification (Corvilain et al. 1991), so the decreased radioiodine content $2 \mathrm{~h}$ after its administration might be related to the decreased DuOx activity. This result highlights the importance of the duration of treatment with RA and the isomer used in order to achieve the desirable effect. It is known that radioiodide uptake per se is important although not sufficient for its therapeutic effectiveness.

On the other hand, 13-cis-RA significantly increased radioiodide uptake in both doses used when the rats were treated for 28 days. Increased NIS function after RA treatment is in agreement with data shown by Schmutzler et al. (2002). However, the increased radioiodine content was only detected in rats treated with the highest dose of
13-cis-RA. This result reinforces the concept that an increase in NIS function does not necessarily lead to increased thyroid radioiodine content. In this sense, $\mathrm{H}_{2} \mathrm{O}_{2}$ generation was increased in rats treated with the highest dose of 13-cis-RA for

Table 2 Effect of all-trans-retinoic acid (RA) and 13-cis-RA for 28 days in the doses of 100 and $1500 \mu \mathrm{g} / \mathrm{kg}$ body weight (b.w.) on serum total thyroxine $\left(\mathrm{T}_{4}\right)$ levels. Results are expressed as mean \pm S.E.M.

\begin{tabular}{l}
$\mathbf{T}_{\mathbf{4}}(\mu \mathrm{g} / \mathrm{dl})$ \\
\hline $5 \cdot 5 \pm 0 \cdot 3(n=19)$ \\
$5 \cdot 9 \pm 0 \cdot 4(n=11)$ \\
$6 \cdot 1 \pm 0 \cdot 7(n=11)$ \\
$5 \cdot 0 \pm 0 \cdot 3(n=11)$ \\
$5 \cdot 4 \pm 0 \cdot 3(n=10)$
\end{tabular}


28 days, showing again the importance of DuOx activity as a limiting step for iodine organification.

The effects of RA treatment on the thyroid of male rats were similar to those found in female rats, as previously described by our group (Silva et al. 2009), suggesting no gender-specific difference regarding thyroid response to RA treatment.

To our knowledge, we have reported herein for the first time the regulatory effect of RA on DuOx activity. As reviewed by Lambeth et al. (2007), DuOx1 and DuOx2 expression are regulated in both thyroid and non-thyroid cells by a promoter region within $-150 \mathrm{bp}$ of the first exon of DuOx1 and within $-250 \mathrm{bp}$ of DuOx2. In dog and pig thyrocytes, cAMP, which is a pathway downstream of the TSH receptor, increases DuOx protein and mRNA (Dupuy et al. 1999, De Deken et al. 2000, Morand et al. 2003). However, no data about a RA-responsive element in $\mathrm{DuOx}$ promoter are available. Pailler-Rodde et al. (1991) have shown that RA induces an increase in PKC activity. Since DuOx is a calcium-dependent NADPH oxidase (Carvalho et al. 1996, Dupuy et al. 1999, Ferreira et al. 2003, Ginabreda et al. 2008), 13-cis-RA could also increase DuOx activity by a stimulatory effect on the calcium pathway. Nevertheless, a direct effect of RA on DuOx promoter cannot be excluded. Further experiments are needed to elucidate the mechanism underlying the effect of RA on DuOx activity.

Even though thyroid iodine organification was significantly decreased in rats treated with all-trans-RA for 14 days and increased in rats treated with 13-cis-RA for 28 days, serum $\mathrm{T}_{4}$ levels remained unchanged. Our data suggest that compensatory mechanisms might take place in order to avoid significant changes in serum $\mathrm{T}_{4}$ levels.

In conclusion, our data suggest that treatment with RA produces direct effects on thyroid function that are dose, isomer and time dependent, suggesting that the efficacy of RA to improve radioiodine therapy might be influenced by these factors. Treatment with $100 \mu \mathrm{g} / 100 \mathrm{~g}$ b.w. of all-trans-RA for 2 weeks reduced thyroid iodine content, while treatment with $1500 \mu \mathrm{g} / 100 \mathrm{~g} \mathrm{b.w}$. of 13-cis-RA increased thyroid iodine content. So it might be important to evaluate serum thyroid hormones and TSH levels in patients under treatment with RA for dermatological and oncological purposes, especially in areas with a low iodine intake and in patients with possible subclinical thyroid dysfunction.

\section{Declaration of interest}

The authors declare that there is no conflict of interest that could be perceived as prejudicing the impartiality of the research reported.

\section{Funding}

This work was supported by grants from $\mathrm{CNPq}$, Departamento de Tireóide/SBEM, FAPERJ/SUS, and FAPERJ/Pensa Rio.

\section{Acknowledgements}

We are grateful for the technical assistance of Norma Lima de Araújo Faria, Advaldo Nunes Bezerra, and Wagner Nunes Bezerra. MM, ACMS, and MPM were recipients of fellowships from CAPES and CNPq

\section{References}

Arai M, Tsushima T, Isozaki O, Shizume K, Emoto N, Demura H, Miyakawa M \& Onoda N 1991 Effects of retinoids on iodine metabolism, thyroid peroxidase gene expression, and deoxyribonucleic acid synthesis in porcine thyroid cells in culture. Endocrinology 129 2827-2833.

Bradford MM 1976 A rapid and sensitive method for the quantitation of microgram quantities of protein utilizing the principle of protein-dye binding. Annals of Biochemistry 72 248-254.

Cardoso LC, Martins DCL, Figueiredo MDL, Rosenthal D, Vaisman M, Violante AHD \& Carvalho DP $2001 \mathrm{Ca}^{2+} /$ nicotinamide adenine dinucleotide phosphate-dependent $\mathrm{H}_{2} \mathrm{O}_{2}$ generation is inhibited by iodide in human thyroids. Journal of Clinical Endocrinology and Metabolism $\mathbf{8 6}$ 4339-4343.

Carvalho DP, Rego KGM \& Rosenthal D 1994 Thyroid peroxidase in dyshormonogenetic goiters with organification and thyroglobulin defects. Thyroid 4 421-426.

Carvalho DP, Dupuy C, Gorin Y, Legue O, Pommier J, Haye B \& Virion A $1996 \mathrm{The}^{2+}$ and reduced nicotinamide adenine dinucleotide phosphate-dependent $\mathrm{H}_{2} \mathrm{O}_{2}$ generation system is induced by thyrotropin in porcine thyroid cells. Endocrinology 137 1007-1012.

Coelho SM, Vaisman M \& Carvalho DP 2004 Tumour re-differentiation effect of retinoic acid: a novel therapeutic approach for advanced tyroid cancer. Current Pharmaceutical Design 10 1-7.

Corvilain B, Van Sande J, Laurent E \& Dumont JE 1991 The $\mathrm{H}_{2} \mathrm{O}_{2}$ generating system modulates protein iodination and the activity of the pentose phosphate pathway in dog thyroid. Endocrinology 128 779-785.

Coya R, Carro E, Mallo F \& Diéguez C 1997 Retinoic acid inhibits in vivo thyroid-stimulating hormone secretion. Life Sciences 60 247-250.

De Deken X, Wang D, Many MC, Costagliola S, Libert F, Vassart G, Dumont JE \& Miot F 2000 Cloning of two human thyroid cDNAs encoding new members of the NADPH oxidase family. Journal of Biological Chemistry 275 23227-23233.

DeGroot LJ \& Niepomniszcze H 1977 Biosynthesis of thyroid hormone: basic and clinical aspects. Metabolism 26 665-718.

Del Senno L, Rossi R, Gandini D, Piva R, Franceschetti P \& Uberti EC 1993 Retinoic acid-induced decrease of DNA synthesis and peroxidase mRNA levels in human thyroid cells expressing retinoic acid receptor alpha. Life Sciences 53 1039-1048.

Del Senno L, Rossi R, Franceschetti P \& Uberti EC 1994 Expression of alltrans-retinoic acid receptor RNA in human thyroid cells. Biochemistry and Molecular Biology International 33 1107-1115.

Dupuy C, Ohayon R, Valent A, Noël-Hudson MS, Dème D \& Virion A 1999 Purification of a novel flavoprotein involved in the thyroid NADPH oxidase. Cloning of the porcine and human cDNAs. Journal of Biological Chemistry 274 37265-37269.

Ferreira ACF, de Carvalho Cardoso L, Rosenthal D \& de Carvalho DP 2003 Thyroid $\mathrm{Ca}^{2+} / \mathrm{NADPH}$-dependent $\mathrm{H}_{2} \mathrm{O}_{2}$ generation is partially inhibited by propylthiouracil and methimazole. European Journal of Biochemistry 270 2363-2368.

Ferreira ACF, Lima LP, Araújo RL, Müller G, Rocha RP, Rosenthal D \& Carvalho DP 2005 Rapid regulation of thyroid sodium-iodide symporter activity by thyrotropin and iodine. Journal of Endocrinology 184 69-76.

Ginabreda MGP, Cardoso LC, Nobrega FM, Ferreira ACF, Gonçalves MDC, Vaisman M \& Carvalho DP 2008 Negative correlation between thyroperoxidase and dual oxidase $\mathrm{H}_{2} \mathrm{O}_{2}$-generating activities in thyroid nodular lesions. European Journal of Endocrinology 158 223-227.

Kopp P 2005 Thyroid synthesis and secretion: thyroid hormone synthesis. In The Thyroid, edn 9, ch 4, pp 52-76. Eds LE Braverman \& RD Utiger. Philadelphia: Lippincott Williams \& Wilkins. 
Kurebayashi J, Tanaka K, Otsuki T, Moriya T, Kunisue H, Uno M \& Sonoo H 2000 All-trans-retinoic acid modulates expression levels of thyroglobulin and cytokines in a new human poorly differentiated papillary thyroid carcinoma cell line KTC-1. Journal of Clinical Endocrinology and Metabolism 852889.

Lambeth JD, Kawahara T \& Diebold B 2007 Regulation of Nox and Duox enzymatic activity and expression. Free Radical Biology \& Medicine 43 319-331.

Leseney AM, Dème D, Dupuy C, Ohayon R, Chanson P, Sales JP, Carvalho DP, Haye B \& Virion A 1999 Biochemical characterization of a $\mathrm{Ca}^{2+} / \mathrm{NaD}(\mathrm{P}) \mathrm{H}$-dependent $\mathrm{H}_{2} \mathrm{O}_{2}$ generator in human thyroid tissue. Biochimie 81 373-380.

Lima LP, Barros IA, Lisbôa PC, Araújo RL, Silva AC, Rosenthal D, Ferreira AC \& Carvalho DP 2006 Estrogen effects on thyroid iodide uptake and thyroperoxidase activity in normal and ovariectomized rats. Steroids 71 653-659.

Morand S, Chaaraoui M, Kaniewski J, Deme D, Ohayon R, Noel-Hudson MS, Virion A \& Dupuy C 2003 Effect of iodide on nicotinamide adenine dinucleotide phosphate oxidase activity and Duox 2 protein expression in isolated porcine thyroid follicles. Endocrinology 144 1241-1248.

Moura EG, Rosenthal D \& Carvalho-Guimarães DP 1989 Thyroid peroxidase activity in human nodular goiters. Brazilian Journal of Medical and Biological Research 22 31-39.

Nakashima T \& Taurog A 1978 Improved assay procedures for thyroid peroxidase: applications to normal and adenomatous human thyroid tissue. Clinica Chimica Acta 83 129-140.

Namba H, Yamashita S, Morita S, Villadolid MC, Kimura H, Yokoyama N, Izumi M, Ishikawa N, Ito K \& Nagataki S 1993 Retinoic acid inhibits human thyroid peroxidase and thyroglobulin gene expression in cultured human thyrocytes. Journal of Endocrinological Investigation 16 87-93.
Pailler-Rodde I, Garcin H \& Higueret P 1991 Effect of retinoids on protein kinase $\mathrm{C}$ activity and on the binding characteristics of the tri-iodothyronine nuclear receptor. Journal of Endocrinology 128 245-251.

Pommier J 1978 Solubilization, purification, propriétés moleculaires et mécanisme d'action de la peroxidase thyroidienne. In Méthodologie Experimentale en Physiologie et Physiopathologie Thyroidienne, pp 137-148. Eds R Hornek \& J Nunez. Paris: INSERM.

Royaux IE, Suzuki K, Mori A, Katoh R, Everett LA, Kohn LD \& Green ED 2000 Pendrin, the protein encoded by the Pendred syndrome gene (PDS), is an apical porter of iodide in the thyroid and is regulated by thiroglobulin in FRTL-5 cells. Endocrinology 141 839-845.

Schmutzler C 2001 Regulation of the sodium/iodide symporter by retinoids a review. Experimental and Clinical Endocrinology and Diabetes 109 41-44.

Schmutzler C, Winzer R, Meissner-Weigl J \& Köhrle J 1997 Retinoic acid increases sodium/iodide symporter mRNA levels in human thyroid cancer cell lines and suppresses expression of functional symporter in nontransformed FRTL-5 rat thyroid cells. Biochemical and Biophysical Research Communications 240832.

Schmutzler C, Schmitt TL, Glaser F, Loos U \& Köhrle J 2002 The promoter of the human sodium/iodide-symporter gene responds to retinoic acid. Molecular and Cellular Endocrinology 189 145-155.

Silva AC, Marassi MP, Mühlbauer M, Lourenço AL, Carvalho DP \& Ferreira ACF 2009 Retinoic acid effects on thyroid function of female rats. Life Sciences 84 673-677.

Verschoore M, Bouclier M, Czernielewski J \& Hensby C 1993 Topical retinoids. Their uses in dermatology. Dermatologic Clinics 11 107-115.

Received in final form 26 February 2010

Accepted 8 March 2010

Made available online as an Accepted Preprint

8 March 2010 